\title{
In Vitro Colony Formation by Cryopreserved Primary Human Tumor Cells ${ }^{1}$
}

\author{
E. D. ALLEN, ${ }^{*}$ T. C. GAU, $†$ AND R. B. NATALE* $\dagger$ \\ *Medical Research, Veterans Administration Medical Center, Ann Arbor, and †Department of Internal \\ Medicine, Division of Hematology/Oncology, University of Michigan, Ann Arbor, Michigan 48109
}

Recent advances in semisolid culture techniques have led to the development of a two-layer soft agar system capable of supporting the growth of colony-forming tumor cells obtained directly from human tumor specimens (4). Colony-forming assays have permitted quantitative investigations of the clonogenic compartment in an individual patient's tumor and have been used to study questions of biological $(2,3)$ and clinical $(7,9,10)$ significance. However, the poor viability and short survival time of freshly biopsied human tumor cells have required that cxperiments be conducted as soon as the tumor specimens are obtained, thereby greatly limiting applications of clonogenic assays $(1,5)$. Thus far, no reliable method has been developed to preserve primary tumor cell viability and function for long periods of time.

We, therefore, examined the feasibility of cryopreserving disaggregated cell suspensions derived directly from human tumors. A method of cryopreservation in which tumor cell clonogenicity and biologic behavior remain unaltered would greatly expand the application of clonogenic assays. Although cryopreservation of human cancer cells and their ability to form colonies following thaw has been reported (8), details of procedures with adequate controls have not been described. This report describes the results of several controlled studies using 19 human tumor specimens.

Received January 19, 1983; accepted July 6, 1983.

${ }^{1}$ Supported in part by a grant from the Veterans Administration and A.C.S. Grant $\mathrm{CH} 231$

\section{MATERIALS AND METHODS}

Preparation of cells from primary cancers. Solid tumors were obtained as surgical specimens collected in RPMI 1640 containing $15 \%$ heat-inactivated fetal bovine serum, $1 \%$ PSN antibiotic mixture ( $5 \mathrm{mg}$ penicillin, $5 \mathrm{mg}$ streptomycin, and $10 \mathrm{mg}$ neomycin/ $\mathrm{ml}$ ) and $1 \% \mathrm{~L}$-glutamine [complete RPMI]. The growth media used in this study (RPMI 1640, McCoy's 5A, and CMRL 1066), antibiotic mixture, and sera were obtained from Gibco laboratories, Grand Island, New York. After being minced into small pieces with scalpels, specimens were placed in phosphate-buffered saline containing collagenase (bacterial grade $\mathrm{B}, 100$ units $/ \mathrm{ml}$ ) and stirred for $2 \mathrm{hr}$ at room temperature. Then specimens were passed through 520 $\mu$ - and 140- $\mu \mathrm{m}$-diameter screen mesh (Cellector sieve, Bellco Glass) and $27-\mu \mathrm{m}$ filters to remove debris, cell aggregates, and to yield suspensions containing primarily single cells.

Malignant effusions were collected by standard clinical procedures in sterile 1000 $\mathrm{ml}$ containers containing $10 \mathrm{ml}$ preservativefree heparin $(10,000$ units $/ \mathrm{ml})$. Pellets obtained following centrifugation $(300 \mathrm{~g}, 10$ $\mathrm{min}$ ) were pooled and resuspended in complete RPMI. All centrifugations were done at $0-2^{\circ} \mathrm{C}$ using a Beckman $\mathrm{TJ} 6 \mathrm{R}$ refrigerated centrifuge equipped with a swingingbucket rotor (TH4). Effusions containing red cells were layered over equal volumes of Ficoll (Ficoll-Paque, Pharmacia) and centrifuged $(300 \mathrm{~g}, 30 \mathrm{~min})$. Following centrifugation, the cancer cells which moved to 
the RPMI-Ficoll boundary were collected, mixed with complete RPMI, and centrifuged $(300 \mathrm{~g}, 10 \mathrm{~min})$. The resulting pellet was resuspended in complete RPMI.

Cells obtained from solid tumors and effusions were counted using a hemocytometer and viability was determined by trypan blue exclusion.

Preparation of freezing mixtures. The cryoprotective agents employed in this study were glycerol and dimethylsulfoxide $\left(\mathrm{Me}_{2} \mathrm{SO}\right)$, both used at concentrations of 5 , 10 , and $15 \%(\mathrm{v} / \mathrm{v})$. Freezing mixtures were prepared by adding $2 \times$ the desired concentration of glycerol or $\mathrm{Me}_{2} \mathrm{SO}$ (prepared in complete RPMI, v/v) to an equal volume of cells $\left(2 \times 10^{6}\right.$ in $\left.1.0 \mathrm{ml}\right)$ suspended in complete RPMI. All solutions including cell suspensions were kept on ice $\left(0^{\circ} \mathrm{C}\right)$. The solutions containing the cryoprotectants werc added gradually over $25 \mathrm{~min}$. This was done by addition of $20 \%$ of the total cryoprotectant solution at $5 \mathrm{~min}$ intervals. Preliminary experiments had indicated that rapid addition and removal of the cryoprotectants drastically inhibited colony formation in soft agar. Following addition of the cryoprotectants, the cell suspensions were kept on ice $\left(0^{\circ} \mathrm{C}\right)$ for $60 \mathrm{~min}$.

Duplicate samples (final volume, $2.0 \mathrm{ml}$ ) were prepared at each concentration. One sample was frozen and thawed as described helow while the other was used to assess the effect of adding and removing the cryoprotectants on colony formation. In addition to the samples that received cryoprotectants, $2.0 \times 10^{6}$ cells in complete RPMI $(2.0 \mathrm{ml})$ served as the control (untreated control). To these samples, $13 \mathrm{ml}$ of complete RPMI was gradually added during $15-20 \mathrm{~min}$. Following centrifugation $(300 \mathrm{~g}, 6 \mathrm{~min})$ and removal of the supernatant, the cell pellet was resuspended in enriched CMRL. When cloned (see below) each sample yielded four plates, $5 \times 10^{5}$ cells per plate.

Freeze-thaw procedure. Samples to be frozen $(2.0 \mathrm{ml}$ final volume $)$ were transferred to freczing vials (Cryule vial, Whea- ton, Millville, N.J.). Vials were placed in a metal test tube rack in a $-80^{\circ} \mathrm{C}$ freezer and left overnight. The cooling rate of similar samples was approximately $2.5^{\circ} \mathrm{C} / \mathrm{min}$ to $-15^{\circ} \mathrm{C}\left(0\right.$ to $\left.-15^{\circ} \mathrm{C}\right)$ and $4.5^{\circ} \mathrm{C} / \mathrm{min}$ from -15 to $-80^{\circ} \mathrm{C}$. The following day specimens were transferred to the vapor phase of a liquid nitrogen freezer. Specimens were removed and thawed when growth (colony formation) was observed in the unfrozen, previously treated samples, usually 5-7 days. Specimens were thawed by agitating the vials in a water bath $\left(37^{\circ} \mathrm{C}\right)$ until melting occurred. After the vial was transferred to an ice bath $\left(0^{\circ} \mathrm{C}\right)$, the thawed mixture was removed, gradually mixed with $13 \mathrm{ml}$ complete RPMI, and centrifuged ( $300 \mathrm{~g}, 6 \mathrm{~min}$ ), and the pellet was resuspended in complete CMRL and cloned (four plates).

Growth in the tumor colony-forming assay. Single cells treated as described above were cultured in a two-layer agar system in 35-mm petri plates somewhat modified from that described by Hamburger and Salmon (1). The bottom layer $(1.0 \mathrm{ml})$ had the following composition: $7.9 \mathrm{ml} \mathrm{3 \%}$ agar, $11 \mathrm{ml}$ complete RPMI, $5 \mathrm{ml} \mathrm{3 \%}$ tryptic soy broth, and $20 \mathrm{ml}$ enriched McCoys $(500 \mathrm{ml}$ McCoys 5A medium, $50 \mathrm{ml}$ heat-inactivated horse serum, $6 \mathrm{ml}$ PSN antibiotic mixture, $5 \mathrm{ml} 2.2 \%$ sodium pyruvate, $5 \mathrm{ml} \mathrm{L}$-glutamine $(200 \mathrm{mM})$, and $2 \mathrm{ml} \mathrm{L}$-serine (21 $\mathrm{mg} / \mathrm{ml})$ ).

The top agar layer $(1.0 \mathrm{ml})$, in which 5 $\times 10^{5}$ cells were suspended, had the following composition: $100 \mathrm{ml} \mathrm{CMRL} \mathrm{1066,19.5}$ $\mathrm{ml}$ heat-inactivated horse serum, $2 \mathrm{ml} \mathrm{L}$ glutamine $(200 \mathrm{mM}), 2 \mathrm{ml}$ insulin (100 units $/ \mathrm{ml}), 1 \mathrm{ml}$ ascorbic acid (30 $\mathrm{mM}), 1$ $\mathrm{ml}$ PSN antibiotic mixture, and $0.3 \%$ agar.

Quadruplicate plates were made at each point by adding $0.45 \mathrm{ml}$ of warm agar to $3.7 \mathrm{ml}$ of enriched CMRL 1066 which contained $2 \times 10^{6}$ cells. Depending on the number of cells available, additional control plates were also prepared. Plates were placed in a humidified incubator $\left(7 \% \mathrm{CO}_{2}\right.$ in air, $37^{\circ} \mathrm{C}$ ) and examined daily for colony for- 


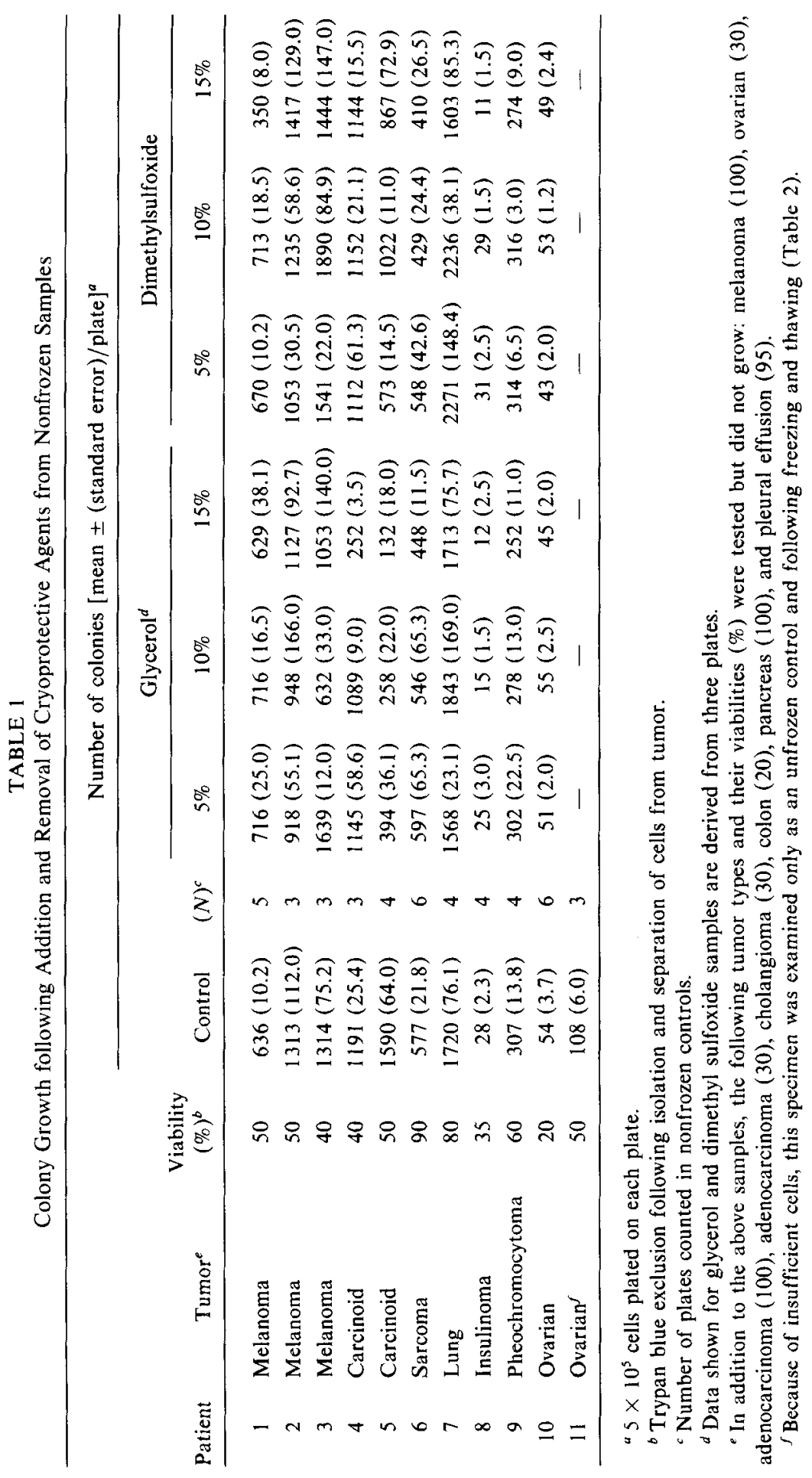


mation. One plate was used for morphological and/or other studies and three were used to determine the number of colonies which grew. Colonies ( $>30$ cells) were scored on the day of maximum growth (Day 10-14) using an inverted Zeiss microscope.

\section{RESULTS AND DISCUSSION}

Tumor cells from 11 to 19 patients formed colonies in the two-layer agar system. The percentage that grew $(58 \%)$ is similar to that found by others and indicates the current level of success in cloning primary cancer cells using this assay system. The median cloning efficiency (number of colonies $/ 500,000$ cells plated $\times 100 \%$ ) in control plates was $0.127 \%$ (range $=0.0056$ $0.344 \%$ ). The percentage cell viability (trypan blue exclusion) of the isolated tumor cell population did not provide insight into whether the specimens would produce colonies. In those specimens which did form colonies, the mean percentage viability was $51.5 \pm 6.5$ (range: $20-90 \%$ ) while that of the specimens which did not was $63.5 \pm 13.5$ (range $20-100 \%$ ) (see Table 1 ).

The effect of exposing cell suspensions to various concentrations of glycerol or $\mathrm{Me}_{2} \mathrm{SO}$ for $1 \mathrm{hr}$ immediately prior to cloning is shown in Table 1. This aspect of the study was undertaken to determine whether the cryoprotectants themselves (in the absence of freezing and thawing) altered colony formation and whether the effect was concentration dependent. Although considerable variation is evident among some of the plates of the individual specimens, in general, $\mathrm{Me}_{2} \mathrm{SO}$ gave better results than glycerol and the 5 and $10 \%$ concentrations of either agent affected colony formation the least. Colony formation was within $10 \%$ of control values at the 5 and $10 \%$ concentrations of cryoprotectants in all 10 specimens exposed to $\mathrm{Me}_{2} \mathrm{SO}$ and in 6 of 10 specimens exposed to glycerol.

In some cases, the highest concentration (15\%) of both glycerol and $\mathrm{Me}_{2} \mathrm{SO}$ caused considerable reduction in the number of col- onies. It is not known whether this reduction was caused by sensitivity of the cells to the cryoprotectants or osmotic damage to cells during addition or removal of the cryoprotectants.

Colony formation following freezing and thawing is shown in Table 2. Survival following cryopreservation with glycerol was very poor, with the majority of specimens yielding no growth at all. Colony formation occurred in 10 of 11 specimens cryopreserved with $\mathrm{Me}_{2} \mathrm{SO}$ and was generally better at the $10 \%$ concentration of this agent than with 5 or $15 \%$. Cloning efficiency was significantly altered $(80 \%$ of nonfrozen controls) in 8 of the 10 specimens which grew. However, cloning efficiency in 8 of 11 specimens was above the level generally regarded as the lower limit for conducting statistically adequate experiments (i.e., 30 colonies/ 500,000 cells plated).

Although 5\% glycerol has been reported to cryopreserve animal tissue culture cells at slow freezing rates (6), it was not a useful agent in this study. Higher glycerol concentrations, which are known to cryopreserve red cells at slow freezing rates, might cryopreserve tumor cells as well, but also might require more elaborate post-thaw washing procedures.

Cryopreservation with $\mathrm{Me}_{2} \mathrm{SO}$ resulted in a significant loss of cloning efficiency in many cases. It is important to know whether the loss was selective or random. That is, does the surviving fraction of clonogenic cells possess the same biologic characteristics (such as cytotoxic drug sensitivity and resistance) as the original tumor cell suspension? We are currently investigating this question.

\section{SUMMARY}

The effect of cryopreservation on the ability of primary human cancer cells to form colonies in a two-layer agar system was examined. Although considerable variation occurred, concentrations of 5 or $10 \%$ dimethylsulfoxide employed with slow 


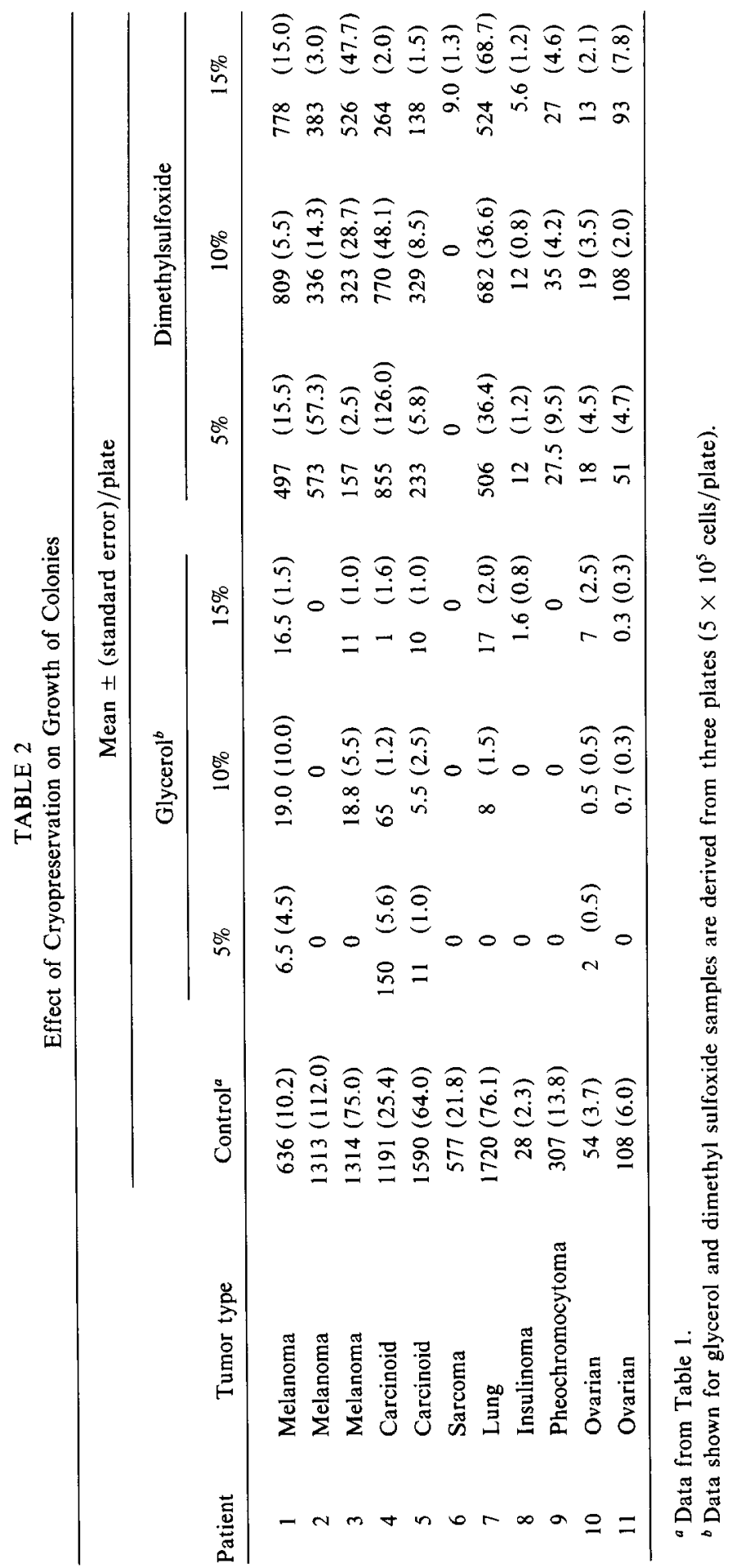


freezing rates allowed survival of colonies in the range $20-40 \%$ or greater of nonfrozen controls. The methods used in this study do not require elaborate freezing equipment, and can be used for the cryopreservation of a wide variety of types of cancers.

\section{REFERENCES}

1. Bertoncello, I., Bradley, T. R., Campbell, J. J., Day, A. J., McDonald, I. A., McLeish, G. R., Quinn, M. A., Rome, R., and Hodgson, G. S. Limitations of the clonal agar assay for the assessment of primary human ovarian tumour biopsies. Brit. $J$. Cancer 45, 803-811 (1982).

2. Buick, R. N., Fry, S. E., and Salmon, S. E. Effect of host cell interactions on clonogenic carcinoma cells in human malignant effusions. Brit. J. Cancer 41, 695-703 (1980).

3. Durie, B. G. M., and Salmon, S. E. Cell kinetic analysis of human tumor stem cells. In "Cloning of Human Tumor Cells” (S. E. Salmon, Ed.), pp 153-163. Alan Liss, New York, 1980.

4. Hamburger, A. W., and Salmon, S. E. Primary bioassay of human tumor stem cells. Science 197, 461-463 (1977).
5. Mackintosh, F. R., Evans, T. L., and Sikic, B. I. Methodologic problems in clonogenic assays of spontaneous human tumors. Cancer Chemother. Pharmacol. 6, 205-210 (1981).

6. Macy, M. L., and Shannon, J. E. Freezing procedures for the preservation of animal cell cultures in liquid nitrogen. In "Cell Biology" (P. I. Altman and D. M. Katz, Eds.), p. 46, Fed. Amer. Soc. Exp. Biol. Bethesda, 1976.

7. Natale, R. B., and Kushner, B. Applications of the human tumor cloning assay to ovarian cancer. Proc. Amer. Assoc. Cancer Res. Amer. Soc. Clin. Oncol. 22, 156 ( 1981 ).

8. Salmon, S. E. "Cloning of Human Tumor Cells." Alan Liss, New York, 1980.

9. Salmon, S. E., Soehnlen, B. J., Durie, B. G. M., Alberts, D. S., Meyskens, F. L., Chen, H. S. G., and Moon, T. E. Clinical correlations of drug sensitivity in tumor stem cell assay. Proc. Amer. Assoc. Cancer Res. Amer. Soc. Clin. Oncol. 20, 340 (1979).

10. Von Hoff, D. D., Casper, J., Bradley, E., Sandbach, J., Jones D., and Makuch, R. Association between human tumor colony-forming assay results and response of an individual patient's tumor to chemotherapy. Amer. J. Med. 70, 1027-1032 (1981). 